\title{
9
}

\section{Legal Institutions, Social Capital, and Financial Crowdfunding: A Multilevel Perspective}

\section{Wanxiang Cai, Friedemann Polzin, and Erik Stam}

\section{Introduction}

The recent emergence of financial investment crowdfunding (i.e., equity and lending crowdfunding) has attracted substantial attention from policy makers and academic researchers alike. Crowdfunding exhibits tremendous potential to support entrepreneurial activities. The market size of equity crowdfunding is expected to reach $\$ 36$ billion by 2020 , exceeding the size of the venture capital market at that time (Cumming et al. Forthcoming). Financial investment crowdfunding (hereafter 'financial crowdfunding') involves a range of risks from an investor's point of view (Kirby and Worner 2014). The great number of 'unsophisticated investors' (defined according to level of income and wealth) in financial crowdfunding makes governance problems more pronounced (Cumming et al. Forthcoming) and thus requires more attention.

Institutions, defined as 'the rules of the game in a society' (North 1991), can mitigate the risks in financial crowdfunding to some extent.

\footnotetext{
W. Cai $(\bowtie) \bullet$ F. Polzin $\bullet$ E. Stam

Utrecht University School of Economics, Utrecht, Netherlands e-mail:w.cai@uu.nl; f.h.j.polzin@uu.nl; e.stam@uu.nl 
Research on venture capital has shown that legal institutions, measured by government effectiveness, quality of regulatory policies, control of corruption, rule of law, political stability, and voice and accountability, have a positive effect on the development of the venture capital market (Li and Zahra 2012). Social capital can to some degree substitute legal institutions in financial markets when legal institutions are deficient (Peng and Heath 1996). Social capital (e.g., trust, reciprocity, and social norms) punishes individuals whose behaviours deviate from social norms (Bowles and Gintis 2002). For instance, in group lending, social capital enhances an individual's willingness to borrow money via monitoring the loans and punishing defaults in a group liability arrangement (Karlan 2007). Especially in a virtual context, in which members temporarily work together to complete a joint task through digital technologies, trust involves establishing and monitoring standards to improve team performance (Crisp and Jarvenpaa 2013). Thus, in crowdfunding contexts, we expect that social capital will contribute to the group outcome (i.e., campaign success).

Previous research on the relationship between social capital and financial crowdfunding has focused mainly on the micro level, that is, how entrepreneurs' social capital affects the success of crowdfunding campaigns and backers' involvement (Vismara 2016; Colombo et al. 2015; Eiteneyer et al. 2019). Little crowdfunding research has investigated the role of legal institutions and social capital at the macro level. To the best of our knowledge, only one paper has empirically demonstrated that both legal institutions and social capital have a positive effect on national crowdfunding volume (Rau 2017). On the one hand, a standard macroto-macro research cannot explicitly identify how legal institutions and social capital affect the development of crowdfunding markets. On the other hand, it is difficult for research at the micro level to take institutional variation into account. Thus, cross-level research may clarify the role of legal institutions and social capital at the macro level in financial crowdfunding governance. For instance, trust in strangers (relational social capital at the macro level) increases investors' propensity to invest in equity crowdfunding (crowdfunding outcomes at the micro level) (Kshetri 2018), and legal institutions can protect investors' benefits, thereby affecting their funding intentions. 
Previous research has suggested that legal institutions at the macro level may not fully explain the heterogeneity in entrepreneurial activities across countries and that the meso level should thus be involved to bridge the research on macro and micro levels (Kim et al. 2016). The effect of legal institutions on financial markets depends not only on the degree to which laws protect investor rights but also on the degree to which those laws are enforced (La Porta et al. 2006).

Crowdfunding involves three main actors: Fundraisers post their project online, crowds observe these projects and decide whether to invest, and platforms function as a bridge to connect fundraisers and investors. A recent study suggested that in crowdfunding campaigns, platforms play the active role of providing due diligence (Cumming and Zhang 2018). To some extent, the due diligence provided by platforms reflects the degree to which platforms enforce legal regulations on crowdfunding, because most regulators require platforms to check the validity of documents provided by issuers before posting their project online. Thus, the protection of investors also relies on platforms' enforcement of regulations on financial crowdfunding. Moreover, social capital embedded in platforms affects the formation of fundraisers' social capital at the micro level. From a micro-to-macro perspective, the number of successful campaigns on platforms and the number of platforms also affect the aggregation of crowdfunding outcomes at the macro level. Thus, we introduce a platform-level analysis that provides a deeper understanding of the relationship among legal institutions, social capital, and crowdfunding performance.

The rest of the chapter is organized as follows: the 'Conceptual Background' section briefly introduces the concepts of legal institutions and social capital, as well as their effect on general financial crowdfunding. 'Crowdfunding and Institutions at Macro and Micro Levels' section clarifies the traditional macro-micro-level model to explain how legal institutions and social capital at both macro and micro levels affect individual crowdfunding campaigns and the development of financial crowdfunding markets. 'Towards a Multilevel Analysis of Financial Crowdfunding and Institutions' section introduces the meso-level analysis. 'Conclusion' section summarizes how legal institutions and social capital affect financial crowdfunding with a three-level model. 


\section{Conceptual Background}

In this section, we introduce the main conceptual building blocks of our study. Two streams of literature have investigated how risks in financial crowdfunding, and entrepreneurial finance more generally, can be mitigated.

\section{Legal Institutions}

Legal institutions play an important role in the governance of financial markets. North (1991) originally highlighted the role of secure property and contractual rights in discouraging investments and specialization. Later research demonstrated that legal institutions are essential in the development of financial markets and entrepreneurial activities. La Porta et al. $(1997,1998)$ explored the effect of legal protections of investors on financial development. They suggested that countries with legal systems which protect the right of investors, enforce private property rights, and support private contractual arrangements have more flourishing financial markets.

More recent research has also demonstrated a relationship between different legal institutions and the development of entrepreneurial finance. For example, legal institutions (aggregated by government effectiveness, rule of law, political stability, voice and accountability, and quality of regulatory policies, etc.) are positively associated with the volume of venture capital in a country (Li and Zahra 2012). Grilli et al. (2016) created a framework to explain how both formal and informal institutions affect venture capital activities. They divided legal institutions into fiscal policy and other legal regulations: tax rate on capital gains, fiscal regulations on investee companies, and corporate income tax are conducive to the development of venture capital activities; other legal regulations, including the legal system, labour regulations, investor protection regulations, and regulations on protection of property rights, affect venture activities as well.

As a novel channel of entrepreneurial finance, financial crowdfunding has some similarities with venture capital; thus, we expect that legal institutions will also influence the development of the financial crowdfunding 
market. A second stream of literature has extensively discussed social capital, as a type of informal institution, in relation to crowdfunding (Cai et al. 2019).

\section{Social Capital}

Social capital is an informal institution that disciplines individuals' behaviours. Adler and Kwon (2002, p. 23) defined social capital as 'the goodwill available to individuals or groups. Its source lies in the structure and content of the actor's social relations. Its effects flow from the information, influence, and solidarity'. In the field of business and economics, especially in relation to finance, social capital has been discussed mainly at micro and macro levels.

At the micro level, Nahapiet and Ghoshal (2000) divided social capital into three dimensions: structural, relational, and cognitive social capital. Regarding entrepreneurial finance, entrepreneurs' structural social capital is normally measured by their social networks, their relational social capital can be measured by investors' trust in them, and their cognitive social capital comprises the shared values, culture, and goals of fundraisers and investors. The authors developed a framework to elaborate on how different dimensions of social capital create intellectual capital through the exchange and combination of knowledge. Later research demonstrated a positive relationship between different dimensions of social capital and access to different forms of entrepreneurial finance. For example, entrepreneurs rely on their social networks to gain access to venture capital (Batjargal and Liu 2004; Shane and Cable 2002). Business angels make use of their structural, relational, and cognitive social capital to identify and evaluate investment opportunities (Sørheim 2003). In banking, network complementarity can enhance a firm's access to bank loans and reduce the cost of capital (Uzzi 1999). Moreover, the shared culture of borrowers and lenders reduces the default rate in group lending (Karlan 2007).

At the macro level, social capital is viewed as a type of soft territorial capital which contributes to regional development (Camagni 2017; Westlund and Bolton 2003). The interplay of different types of social 
relationships leads to dense combinations of such relationships, which are dependent on geographic proximity and thus lay the foundation of regional social capital (Malecki 2012). Westlund and Bolton (2003, p. 79) defined regional social capital as 'spatially-defined norms, values, knowledge, preferences, and other social attributes or qualities that are reflected in human relationship. In regional studies, social capital functions as both "glue" and "lubricant", maintaining cooperation and facilitating the interaction and flows within organizations (Malecki 2012). Social capital has a positive effect on macroeconomic growth (Knack and Keefer 1997), regional innovation, and entrepreneurship (Akçomak and Ter Weel 2009; Feldman and Zoller 2012). Regional social capital also affects the development of financial markets. A previous study suggested that social capital contributes to the development of stock markets in Italy (Guiso et al. 2004). A cross-country study demonstrated a positive relationship between social capital and both financial depth and efficiency (Calderón et al. 2002).

\section{Crowdfunding and Institutions at Macro and Micro Levels}

In this section, we analyse previous research and, based on its results, build a two-level model to elaborate on how legal institutions and social capital affect financial crowdfunding at macro and micro levels.

In line with previous studies (Martínez-Climent et al. 2018; Rau 2017), we focus only on the two types of financial return models (lending and equity). Investors in financial crowdfunding are driven mainly by financial returns, and the motivation to support others ranks among the least important factors (Vismara 2018). Financial crowdfunding is closer to other forms of financial investment, such as microlending, business angels, and venture capital, making it more applicable to economic approaches like signalling theory (Ahlers et al. 2015; Bapna 2017; Vismara 2016). Financial crowdfunding involves higher risks compared to nonfinancial crowdfunding. Among the main risks faced by investors are default or nonpayment, fraud, illiquidity by fundraisers, lack of 
transparency in operations, closing or failure of the platform, and cyberattacks (Kirby and Worner 2014). This is supported by interviews with fundraisers and investors, who indicate that they regard equity crowdfunding investing as high risk and high return (Estrin et al. 2018). Moreover, most investors in financial crowdfunding are less experienced and face large information asymmetries when evaluating the quality of projects (Ahlers et al. 2015; Bapna 2017).

\section{Macro-Level Dynamics}

Some features of financial crowdfunding resemble those of entrepreneurial finance, such as business angels and venture capital (Lukkarinen et al. 2016). For example, in both financial crowdfunding and investment by business angels, investors driven by financial return invest their own funds in projects. In the United Kingdom, angel investors are normally found in equity crowdfunding platforms. In China, on the other hand, most equity crowdfunding platforms adopt the leader-follower model, in which both business angels and venture capitalists do the due diligence for and endorse the projects, thereby attracting subsequent investors. Some research has indicated that equity crowdfunding is more likely to be the complement of business angels (e.g., Hornuf and Schwienbacher 2016). Therefore, we expect that the influence of both legal institutions and social capital on financial crowdfunding will be similar to that on other entrepreneurial financial sources, such as business angels and venture capital.

Rau (2017) investigated the correlation between legal institutions and crowdfunding volume. He focused on the effect of overall legal regimes (the regulations on financial crowdfunding are excluded). He found that overall legal regimes (including control of corruption and the overall financial market development) and social capital (measured by trust in strangers) have a positive effect on national financial crowdfunding volume. Because legal regimes and regulations on financial crowdfunding may have different effects on crowdfunding volume, we discuss them separately. 
Regulations on financial crowdfunding protect investors by setting requirements for the minimum income or net assets to enter the market (Hornuf and Schwienbacher 2017). The effect of regulations on crowdfunding might play out differently: On the one hand, the protections of investors encourage them to invest in financial crowdfunding. For example, a recent report found a positive relationship between the platform owners' perceived adequacy of regulation and national crowdfunding volume (Ziegler et al. 2019). On the other hand, excessively strong protections of investors reduce the number of qualified investors and harm the motivation of fundraisers. Hence, regulators need to strike a balance between crowdfunding market promotion and the protection of retail investors.

As for social capital, Rau (2017) quantitatively demonstrated that trust in strangers has a positive effect on national financial crowdfunding volume. Therefore, we suggest that social capital at the macro level may have a positive impact on the development of financial crowdfunding markets.

\section{Micro-Level Dynamics}

At the micro level, we discuss only the role of social capital. Previous research on crowdfunding has examined the determinants of crowdfunding success mainly at the micro level and has demonstrated that structural, relational, and cognitive dimensions of social capital affect the success of crowdfunding campaigns at the micro level (Cai et al. 2019).

Previous research on structural social capital in financial crowdfunding has suggested that entrepreneurs can make use of their private social networks (i.e., family and friends) to raise money (Lukkarinen et al. 2016). The size of entrepreneurs' social networks is perceived as reflecting the quality of the project and thereby attracts more investors to support the campaign (Vismara 2016). Such investor networks can trigger herding, which increases the chance of campaign success (Liu et al. 2015).

Regarding relational social capital, investors' trust in fundraisers plays an important role in their decision-making. In lending crowdfunding, lenders' economic status, including credit grades, verified bank accounts, and debt-to-income ratio, reflects their ability to pay the interest on time, 
thereby exerting a positive influence on crowdfunding success (Greiner and Wang 2010). Previous successful campaigns are also positively associated with fundraisers' trustworthiness (Yum et al. 2012). Other measurements of trust in fundraisers include third-party endorsements (Greiner and Wang 2010; Chen et al. 2016), entrepreneur-sponsor interactions (Xu and Chau 2018), and the disclosure of personal information (Ge et al. 2017). All of these studies demonstrated that investors' trust in fundraisers encourages them to invest in the projects.

Cognitive social capital has received less attention in financial crowdfunding research. Only one paper has investigated lending crowdfunding. Burtch et al. (2014) found that the cultural distance between borrowers and lenders has a negative influence on lending actions.

\section{Interactions Between Financial Crowdfunding and Institutions at Macro and Micro Levels}

Above, we show that both legal institutions and social capital at the macro level affect individual behaviours at the micro level, thereby affecting the performance of individual crowdfunding campaigns (macro-micro mechanism). This mechanism is depicted in Fig. 9.1.

Legal institutions at the macro level affect individual crowdfunding campaigns directly and through the mediation effect of social capital. First, mandatory information disclosure requires firms to post certain information on the platform, which can send signals reflecting the quality of the projects to potential investors (Ahlers et al. 2015). Such signals can reduce the information asymmetry between investors and entrepreneurs, helping them evaluate the true value of the projects. Moreover, legal protections of investors encourage them to invest in the project without worrying about potential defaults in crowdfunding.

Legal institutions are positively associated with trust (Berggren and Jordahl 2006). The enormous risks associated with financial crowdfunding discourage investors to support campaigns. Stronger legal protections of investors can increase their trust in both the project and fundraisers: First, comprehensive registration requirements allow only high-quality projects to be listed on the platform (Cumming and Zhang 2018), 


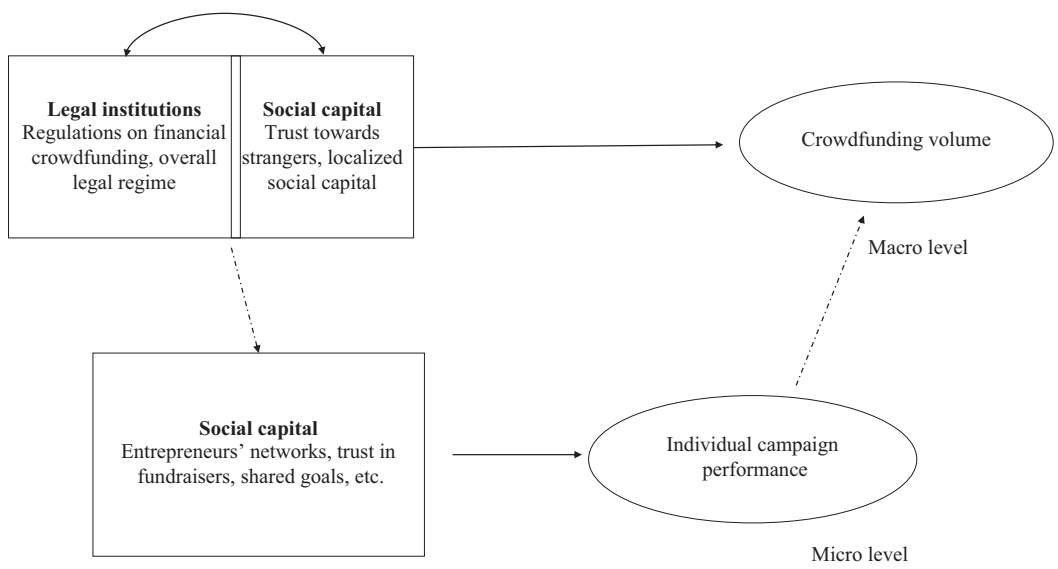

Note:Solid arrows indicate direct effects, whereas dotted arrows indicate indirect effects

Fig. 9.1 Interactions between financial crowdfunding and institutions at macro and micro levels

increasing investors' trust in the campaign. Stricter legal regulations prevent fundraisers from intentionally deceiving investors, thereby enhancing investors' trust that fundraisers are listing projects in good faith. Thus, the legal institutions affect individual crowdfunding campaigns by increasing investors' trust in the projects. Based on these arguments, we put forward our first proposition:

Proposition 1 Social capital at the micro level can mediate the effect of legal institutions on the success of individual crowdfunding campaigns.

Social capital at the macro level also has an impact on individual crowdfunding campaigns. Giudici et al. (2018) measured localized relational social capital by the number of nonprofit organizations, recycling, voter turnout, and satisfaction with relationships with friends. They found that social capital at the macro level affects the performance of reward-based crowdfunding campaigns by enhancing the effect of local altruism on the contributions from local investors. In a qualitative study of equity crowdfunding, Kshetri (2018) argued that investors' trust in strangers increases their tendency to invest in the projects. Therefore, 
social capital at the macro level has a positive effect on the performance of crowdfunding campaigns.

The aggregation of crowdfunding success at the micro level affects the crowdfunding volume at the macro level. In line with prior findings that excessively strong legal protection of crowdfunders may reduce the number of crowdfunding campaigns in a country, stronger legal institutions may not lead to higher regional crowdfunding volume. Thus, higher individual crowdfunding performance does not entail higher regional crowdfunding volume. In fact, before 2015, the United States allowed only sophisticated investors to enter crowdfunding markets, but the country subsequently lowered the requirement in an effort to attract more funding from small investors.

Entrepreneurship research has suggested that social capital plays a more important role when legal institutions are weaker. For instance, in emerging economies, venture capitalists rely on social relationships and their networks to screen potential investment opportunities and monitor investees (Ahlstrom and Bruton 2006). Moreover, the effect of trust on financial development is less important when the legal system is more efficient (Guiso et al. 2004). A comparative study indicated that the effect of fundraisers' social capital on campaign success in China is higher than that in the United States (Zheng et al. 2014). Although the authors attributed this finding to cultural differences between the two countries, it still indicates that in a developing market, investors rely on social sanctions to protect their benefits. Therefore, we believe that entrepreneurs' social capital, as well as social capital at the macro level, can replace legal institutions in financial crowdfunding; that is, when the legal institutions are weaker, fundraisers' social capital has a stronger effect on crowdfunding success. Thus, we arrive at our second proposition:

Proposition 2 Legal institutions moderate the relationship between social capital (at both macro and micro levels) and individual crowdfunding success. 


\section{Towards a Multilevel Analysis of Financial Crowdfunding and Institutions}

\section{The Role of Platforms in Crowdfunding}

Crowdfunding platforms are an active intermediary between entrepreneurs and investors. First, they enforce the regulations on financial crowdfunding to supervise transactions between investors and fundraisers. Second, they establish specific rules to reduce potential risks in crowdfunding. Finally, they provide some value-added services for projects.

On financial crowdfunding platforms, inexperienced investors face abundant risks. Regulators require fundraisers to publish a prospectus and platforms to ensure the validity of information disclosed by fundraisers. Therefore, platforms conduct due diligence for fundraisers to mitigate the information asymmetry between fundraisers and investors. They aim at sorting out both lower-quality projects and lower-quality investors. The degree of due diligence varies across platforms. Fierce competition among platforms may result in allowing unsecured fundraisers to enter the market (Yoon et al. 2019). In fact, some regulators (e.g., the Financial Conduct Authority in the United Kingdom) did not establish specific requirements for information disclosure, allowing crowdfunding platforms to follow their own standards for due diligence. Further, to attract more funding, some platforms did not check the qualifications of investors. A popular article attributed the increasing default rates of Chinese P2P lending projects partly to platforms' practice of pooling funds illegally from investors (Liu 2018). Moreover, UK platforms are obligated to educate investors about the risks involved in financial crowdfunding. Apparently, the degree to which investors are educated varies: Some platforms list only the potential risks for investors, whereas others require investors to pass a test during the registration process.

Second, platforms create their own rules for running campaigns, which affect the behaviours of both entrepreneurs and crowdfunders. There are two main types of business models for crowdfunding: 'all-or-nothing' and 'keep-it-all'. In the all-or-nothing model, only successful campaigns 
can collect money from investors, making entrepreneurs more likely to disclose information about the projects to ensure the success of the crowdfunding project (Cumming and Zhang 2018). Platforms also establish different rules for investors' decision-making. For instance, in some platforms, all investors have to make decisions together (e.g., investors in AngelList have to join a syndicate and follow a leader to invest in certain projects), whereas in most other platforms, investors can make decisions independently. In some P2P lending platforms, borrowers must disclose their economic status (e.g., debt-to-income ratio, credit grades, verified bank accounts), which reflect their ability to the money (Greiner and Wang 2010). Recently, some platforms (e.g., Zopa and Lending Club) have adopted artificial intelligence to create credit scores for borrowers. In Chinese P2P lending markets, platforms have adopted various methods of reducing potential risks involved in investing, including risk reserves funding, third-party endorsements, and fund custodian mechanisms (Yoon et al. 2019). The fee structure also influences platformspecific rules. Platforms which charge fees only for successful projects are more willing to conduct due diligence, whereas those that receive fees from all projects may devote less effort to due diligence (Cumming and Zhang 2018).

Overall, platforms provide a series of additional services for fundraisers to pursue crowdfunding success and even future funding successes, including promotion services, business planning, financial analysis, strategic guidance, exist assistance, and advisory services for future funding (Cumming and Zhang 2018; Rossi and Vismara 2018). Both theoretical and empirical research have investigated how these services affect individual crowdfunding success. For instance, Wu et al. (2018) built a theoretical model to examine how the quality and matching services provided by platforms affect their performance. They suggested that excluding low-quality projects is profitable if investors' preference for project quality is substantial enough. Rossi and Vismara (2018) tested the relationship between platform services and the number of successful campaigns. They found that only post campaign services offered by platforms (e.g., exit assistance, second market, advisory services for future funding, etc.) positively affect the number of successful campaigns. 


\section{Platforms as the Meso Level}

As discussed above, a simple macro-micro-level research design may face two analytical shortcomings: the ecological fallacy and disaggregation bias (Kim et al. 2016). In our case, the ecological fallacy means that the inferences of macro-to-micro research may be misleading if they are attributed to a lower level of analysis. Thus, it might be arbitrary to attribute the negative effect of excessively strong protection of investors on crowdfunding volume to the damage of entrepreneurial initiatives. Disaggregation bias describes situations in which the results of microlevel research may not be transferable to the macro level. Therefore, we cannot simply conclude that the results at the micro level can be replicated at the macro level or vice versa. A recent study suggested that the factors that contribute to crowdfunding success vary across platforms (Dushnitsky and Fitza 2018), which indicates that crowdfunding research should take into consideration the nature of the platform.

For two reasons, we follow Kim et al. (2016) by introducing the platform as a meso-level factor in the multilevel analysis of institutions and financial crowdfunding. First, both social capital and legal institutions exist at the meso level. Through interactions among participants, trust, networks and shared goals can be developed on crowdfunding platforms (Cai et al. 2019), while platforms create their own rules and business models, which to some extent can be seen as regulations at the meso level (e.g., establishing specific information-disclosure requirements, designing mechanisms to reduce potential risks, educating investors, and using specific fee structures).

Second, platforms are essential in creating social capital and enforcing legal institutions in crowdfunding activities. The term 'crowdfunding community' has been used widely in crowdfunding research (e.g., Belleflamme et al. 2014; Agrawal et al. 2014). Even in financial crowdfunding, investors can also benefit from 'community benefits', such as investment experience (Belleflamme et al. 2014). Thus, investors rely to some extent on interactions with others to alleviate information asymmetry in financial crowdfunding (Liu et al. 2015; Wang et al. 2019). In addition, platforms conduct due diligence as well as put forward 
platform policies, which not only enforce the legal institutions at the macro level but also strengthen trust among investors. This forms the basis for our third proposition:

Proposition 3 Crowdfunding platforms at the meso level mediate the effect of legal institutions and social capital on crowdfunding success.

Social capital and legal institutions are associated with social capital and legal institutions at other levels. For example, trust can penetrate to other levels; that is, the higher the trust towards strangers (macro level), the higher the trust towards platforms and fundraisers will be. In addition, legal institutions at the macro level affect crowdfunding campaigns through the enforcement of regulations. Furthermore, legal institutions also affect trust at different levels (this phenomenon is discussed further in the next section). Thus, we suggest that platforms constitute the meso level in a multilevel model, which can mitigate both the ecological fallacy and the disaggregation bias.

Although social capital is a multidimensional concept, we focus only on trust-the most frequently discussed dimension in social-capitalbased research on financial crowdfunding - in our three-level model. This approach can clearly explain how social capital and legal institutions across different levels jointly affect financial crowdfunding.

\section{Three-Level Model of Institutions and Financial Crowdfunding}

Legal institutions and social capital at the macro level can directly and indirectly (via social capital) affect crowdfunding campaigns. The direct effect can be seen in the two-level model proposed above. The meso level plays an important role in the indirect effect. The degree to which legal institutions protect investors also depends on the enforcement of regulations by crowdfunding platforms. Only strong enforcement of regulations on financial crowdfunding by platforms enhances the protection of investors, affecting their decision-making. Moreover, platforms may follow their own standards in information disclosure, which can affect the 
number and the content of signals sent by projects' information, which can in turn mitigate the information asymmetry between investors and fundraisers. Second, platforms must educate and select investors. If platforms allow only qualified investors to enter the markets and inform them of potential risks, investors have a greater chance of identifying high-quality campaigns.

Legal institutions also affect social capital on both meso and micro levels. Regulations on financial crowdfunding affect the quality of platforms, because they can operate only after being approved by the financial authority. Only high-quality platforms are allowed to operate, which enhances investors' trust that platforms are a reliable venue on which to invest and can protect their interests. Second, regulations on financial crowdfunding may clarify platforms' responsibility for conducting due diligence. For instance, in the United Kingdom, platforms must ensure that the information disclosure of the project is fair, clear, and not misleading (FCA n.d.). Thus, platforms which conduct adequate due diligence receive higher trust from investors, because such due diligence enables investors to screen low-quality projects (Cumming and Zhang 2018).

Trust at macro and meso levels increases the trust in fundraisers, thereby enhancing their funding intentions. Trust at the macro level (trust in strangers) reflects people's willingness to be vulnerable to others' actions (Mayer et al. 1995). In financial crowdfunding, investors risk losing their money. Higher trust at the macro level may increase investors' trust in platforms and fundraisers, because they are more willing to take the risks involved in crowdfunding investments. Moreover, investors' trust at the meso level increases their trust in fundraisers, because platforms enforce rules for the listed projects. Empirical research has demonstrated that trust in platforms (meso level) is positively associated with trust in fundraisers (micro level) (Chen et al. 2014).

We suggest that the relationship between crowdfunding outcomes at micro and macro levels requires further elaboration, especially regarding the role of platforms. First, legal institutions affect the creation of platforms. For instance, Dushnitsky et al. (2016) found that the strength of legal rights in a country's credit market has a positive effect on the creation of lending crowdfunding platforms and a negative influence on 


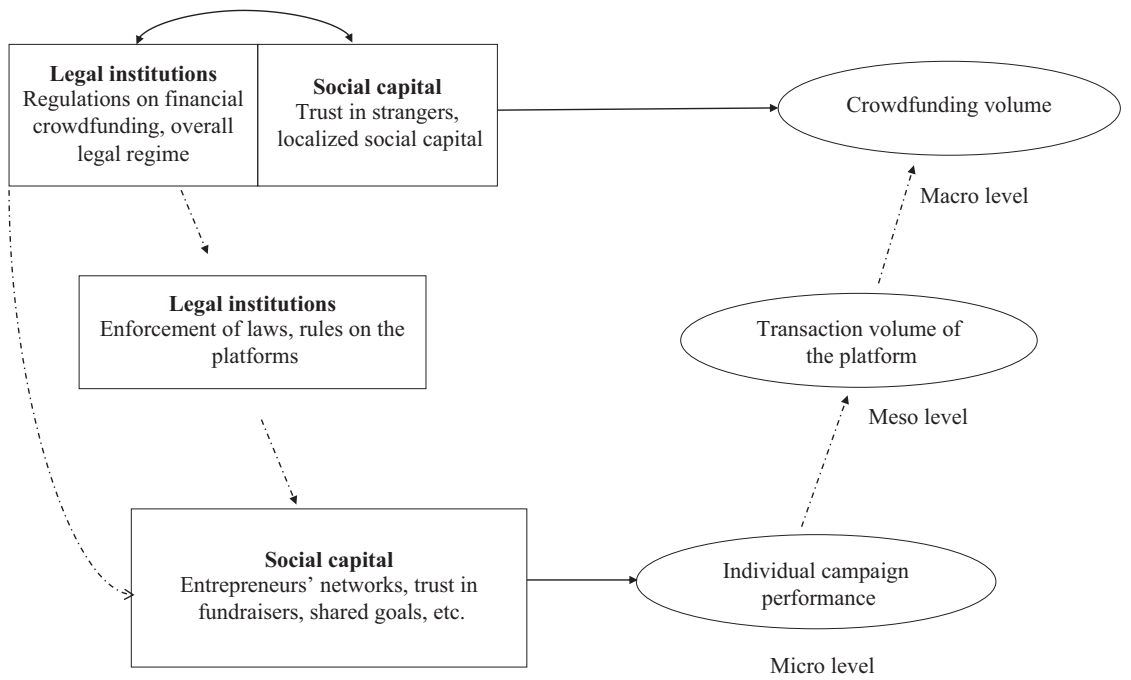

Fig. 9.2 Interactions between financial crowdfunding and institutions at macro, meso, and micro levels

equity crowdfunding platforms. Second, the services of platforms also affect the number of successful campaigns conducted on them. For instance, post campaign services increase the number of successful campaigns on a platform (Rossi and Vismara 2018). Therefore, taking platforms into account may provide a deep understanding of how the aggregation of successful crowdfunding campaigns affects regional crowdfunding volume. Figure 9.2 illustrates the overall framework of the threelevel model.

\section{Conclusion}

Using a two-level model, this chapter explains how legal institutions and social capital at macro and micro levels affect crowdfunding performance across micro and macro levels. We suggest that legal institutions and social capital (at both macro and micro levels) affect crowdfunding campaigns and that the role of social capital may replace that of legal institutions in financial investment crowdfunding. 
To enhance the explanatory power of the two-level model, we introduce crowdfunding platforms as a meso level. We explain the role of platforms in the crowdfunding market and then elaborate on the mechanism by which the meso level bridges macro- and micro-level analyses. Platforms moderate the effect of regulations on financial crowdfunding and increase investors' trust in fundraisers by due diligence. The number of successful campaigns of platforms and the total number of platforms in turn affects the aggregation of crowdfunding outcomes at the macro level. These mechanisms improve our understanding of the role of platforms in the development of financial crowdfunding markets.

This chapter suggests directions for future crowdfunding research. Compared to micro-level research, macro- and meso-level crowdfunding studies are rare. To determine whether the empirical results of micro-level research can be replicated at meso and macro levels, more empirical evidence is required. Furthermore, the interactions between legal institutions and social capital across different levels require more exploration. This chapter provides a framework for conducting such research (e.g., analysing the moderation of due diligence on the relationship between legal institutions at the macro level and individual crowdfunding campaigns).

This chapter also has practical implications for both policy makers and platform owners. On the one hand, policy makers should consider the enforcement of regulations by crowdfunding platforms. Although most regulators demand that platforms ensure the validity of information disclosed by fundraisers, supervision of platforms is lacking. Only if platforms follow relevant regulations on crowdfunding can these regulations effectively regulate the crowdfunding market. On the other hand, platform owners should recognize the role of platform rules in platform performance. By adopting suitable rules and a suitable business model, owners can improve their business performance.

\section{References}

Adler, P. S., \& Kwon, S.-W. (2002). Social Capital: Prospects for a New Concept. Academy of Management Review, 27(1), 17-40.

Agrawal, A., Catalini, C., \& Goldfarb, A. (2014). Some Simple Economics of Crowdfunding. Innovation Policy and the Economy, 14(1), 63-97. 
Ahlers, G. K. C., Cumming, D., Günther, C., \& Schweizer, D. (2015). Signaling in Equity Crowdfunding. Entrepreneurship Theory and Practice, 39(4), 955-980.

Ahlstrom, D., \& Bruton, G. D. (2006). Venture Capital in Emerging Economies: Networks and Institutional Change. Entrepreneurship Theory and Practice, 30(2), 299-320.

Akçomak, İ. S., \& ter Weel, B. (2009). Social Capital, Innovation and Growth: Evidence from Europe. European Economic Review, 53(5), 544-567.

Bapna, S. (2017). Complementarity of Signals in Early-Stage Equity Investment Decisions: Evidence from a Randomized Field Experiment. Management Science, 65(2), 933-952.

Batjargal, B., \& Liu, M. (2004). Entrepreneurs' Access to Private Equity in China: The Role of Social Capital. Organization Science, 15(2), 159-172. Belleflamme, P., Lambert, T., \& Schwienbacher, A. (2014). Crowdfunding: Tapping the Right Crowd. Journal of Business Venturing, 29(5), 585-609.

Berggren, N., \& Jordahl, H. (2006). Free to Trust: Economic Freedom and Social Capital. Kyklos, 59(2), 141-169.

Bowles, S., \& Gintis, H. (2002). Social Capital and Community Governance. The Economic Journal, 112(483), F419-F436.

Burtch, G., Ghose, A., \& Wattal, S. (2014). Cultural Differences and Geography as Determinants of Prosocial Lending. MIS Quarterly, 38(3), 773-794.

Cai, W., Polzin, F., \& Stam, E. (2019). Crowdfunding and Social Capital: A Systematic Literature Review. SSRN Scholarly Paper ID 3361748. Rochester, NY: Social Science Research Network. Retrieved from https://papers.ssrn. com/abstract $=3361748$.

Calderón, C., Chong, A., \& Galindo, A. (2002). Development and Efficiency of the Financial Sector and Links with Trust: Cross-Country Evidence. Economic Development and Cultural Change, 51(1), 189-204.

Camagni, R. (2017). Regional Competitiveness: Towards a Concept of Territorial Capital. In R. Capello (Ed.), Seminal Studies in Regional and Urban Economics: Contributions from an Impressive Mind (pp. 115-131). Cham: Springer International Publishing.

Chen, D., Lai, F., \& Lin, Z. (2014). A Trust Model for Online Peer-to-Peer Lending: A Lender's Perspective. Information Technology and Management, 15(4), 239-254.

Chen, X., Zhou, L., \& Wan, D. (2016). Group Social Capital and Lending Outcomes in the Financial Credit Market: An Empirical Study of Online Peer-to-Peer Lending. Electronic Commerce Research and Applications, 15, 1-13. 
Colombo, M. G., Franzoni, C., \& Rossi-Lamastra, C. (2015). Internal Social Capital and the Attraction of Early Contributions in Crowdfunding. Entrepreneurship Theory and Practice, 39(1), 75-100.

Crisp, C. B., \& Jarvenpaa, S. L. (2013). Swift Trust in Global Virtual Teams:

Trusting Beliefs and Normative Actions. Journal of Personnel Psychology, 12(1), 45-56.

Cumming, D. J., \& Zhang, Y. (2018). Are Crowdfunding Platforms Active and Effective Intermediaries? SSRN Scholarly Paper ID 2882026. Rochester, NY: Social Science Research Network. Retrieved from https://papers.ssrn.com/ abstract $=2882026$.

Cumming, D. J., Vanacker, T., \& Zahra, S. A. (Forthcoming). Equity Crowdfunding and Governance: Toward an Integrative Model and Research Agenda. Academy of Management Perspectives.

Dushnitsky, G., \& Fitza, M. A. (2018). Are We Missing the Platforms for the Crowd? Comparing Investment Drivers Across Multiple Crowdfunding Platforms. Journal of Business Venturing Insights, 10, e00100.

Dushnitsky, G., Guerini, M., Piva, E., et al. (2016). Crowdfunding in Europe: Determinants of Platform Creation Across Countries. California Management Review, 58(2), 44-71.

Eiteneyer, N., Bendig, D., \& Brettel, M. (2019). Social Capital and the Digital Crowd: Involving Backers to Promote New Product Innovativeness. Research Policy, 48(8), 103744.

Estrin, S., Gozman, D., \& Khavul, S. (2018). The Evolution and Adoption of Equity Crowdfunding: Entrepreneur and Investor Entry into a New Market. Small Business Economics, 51(2), 425-439.

Feldman, M., \& Zoller, T. D. (2012). Dealmakers in Place: Social Capital Connections in Regional Entrepreneurial Economies. Regional Studies, 46(1), 23-37.

Financial Conduct Authority. (n.d.). FCA Handbook. Retrieved May 21, 2019, from https://www.handbook.fca.org.uk/handbook/COBS/.

Ge, R., Feng, J., Gu, B., et al. (2017). Predicting and Deterring Default with Social Media Information in Peer-to-Peer Lending. Journal of Management Information Systems, 34(2), 401-424.

Giudici, G., Guerini, M., \& Rossi-Lamastra, C. (2018). Reward-Based Crowdfunding of Entrepreneurial Projects: The Effect of Local Altruism and Localized Social Capital on Proponents' Success. Small Business Economics, 50(2), 307-324.

Greiner, M. E., \& Wang, H. (2010). Building Consumer-to-Consumer Trust in E-Finance Marketplaces: An Empirical Analysis. International Journal of Electronic Commerce, 15(2), 105-136. 
Grilli, L., Latifi, G., \& Mrkajic, B. (2016). Institutional Determinants of Venture Capital Activity: A Survey of the Literature and a Research Agenda. SSRN Scholarly Paper ID 3105441. Rochester, NY: Social Science Research Network. Retrieved from https://papers.ssrn.com/abstract=3105441.

Guiso, L., Sapienza, P., \& Zingales, L. (2004). The Role of Social Capital in Financial Development. American Economic Review, 94(3), 526-556.

Hornuf, L., \& Schwienbacher, A. (2016). Crowdinvesting: Angel Investing for the Masses? In H. Landström \& C. Mason (Eds.), Handbook of Research on Business Angels (pp. 381-398). Cheltenham: Edward Elgar.

Hornuf, L., \& Schwienbacher, A. (2017). Should Securities Regulation Promote Equity Crowdfunding? Small Business Economics, 49(3), 579-593.

Karlan, D. S. (2007). Social Connections and Group Banking. The Economic Journal, 117(517), F52-F84.

Kim, P. H., Wennberg, K., \& Croidieu, G. (2016). Untapped Riches of MesoLevel Applications in Multilevel Entrepreneurship Mechanisms. Academy of Management Perspectives, 30(3), 273-291.

Kirby, E., \& Worner, S. (2014). Crowd-Funding: An Infant Industry Growing Fast. Staff Working Papers. IOSCO Research Department.

Knack, S., \& Keefer, P. (1997). Does Social Capital Have an Economic Payoff? A Cross-Country Investigation. The Quarterly Journal of Economics, 112(4), 1251-1288.

Kshetri, N. (2018). Informal Institutions and Internet-Based Equity Crowdfunding. Journal of International Management, 24(1), 33-51.

La Porta, R., Lopez-de-Silanes, F., Shleifer, A., \& Vishny, R. W. (1997). Legal Determinants of External Finance. The Journal of Finance, 52(3), 1131-1150.

La Porta, R., Lopez-de-Silanes, F., \& Shleifer, A. (2006). What Works in Securities Laws? The Journal of Finance, 61(1), 1-32.

Li, Y., \& Zahra, S. A. (2012). Formal Institutions, Culture, and Venture Capital Activity: A Cross-Country Analysis. Journal of Business Venturing, 27(1), 95-111.

Liu, J. (2018). The Dramatic Rise and Fall of Online P2P Lending in China. TechCrunch (blog). Retrieved May 24, 2019, from http://social.techcrunch. com/2018/08/01/the-dramatic-rise-and-fall-of-online-p2p-lendingin-china/.

Liu, D., Brass, D. J., Lu, Y., et al. (2015). Friendships in Online Peer-to-Peer Lending: Pipes, Prisms, and Relational Herding. MIS Quarterly, 39(3), 729-7A4.

Lukkarinen, A., Teich, J. E., Wallenius, H., et al. (2016). Success Drivers of Online Equity Crowdfunding Campaigns. Decision Support Systems, $87,26-38$. 
Malecki, E. J. (2012). Regional Social Capital: Why It Matters. Regional Studies, 46(8), 1023-1039.

Martínez-Climent, C., Zorio-Grima, A., \& Ribeiro-Soriano, D. (2018). Financial Return Crowdfunding: Literature Review and Bibliometric Analysis. International Entrepreneurship and Management Journal, 14(3), 527-553.

Mayer, R. C., Davis, J. H., \& Schoorman, D. F. (1995). An Integrative Model of Organizational Trust. Academy of Management Review, 20(3), 709-734.

Nahapiet, J., \& Ghoshal, S. (2000). Social Capital, Intellectual Capital, and the Organizational Advantage. In Knowledge and Social Capital (pp. 119-157). Boston: Butterworth-Heinemann.

North, D. C. (1991). Institutions. Journal of Economic Perspectives, 5(1), 97-112. Peng, M. W., \& Heath, P. S. (1996). The Growth of the Firm in Planned Economies in Transition: Institutions, Organizations, and Strategic Choice. Academy of Management Review, 21(2), 492-528.

Porta, R., Lopez-de-Silanes, F., Shleifer, A., \& Vishny, R. W. (1998). Law and Finance. Journal of Political Economy, 106(6), 1113-1155.

Rau, P. R. (2017). Law, Trust, and the Development of Crowdfunding. Cambridge Centre for Alternative Finance Conference. Cambridge, UK.

Rossi, A., \& Vismara, S. (2018). What Do Crowdfunding Platforms Do? A Comparison Between Investment-Based Platforms in Europe. Eurasian Business Review, 8(1), 93-118.

Shane, S., \& Cable, D. (2002). Network Ties, Reputation, and the Financing of New Ventures. Management Science, 48(3), 364-381.

Sørheim, R. (2003). The Pre-Investment Behaviour of Business Angels: A Social Capital Approach. Venture Capital, 5(4), 337-364.

Uzzi, B. (1999). Embeddedness in the Making of Financial Capital: How Social Relations and Networks Benefit Firms Seeking Financing. American Sociological Review, 54(4), 481-505.

Vismara, S. (2016). Equity Retention and Social Network Theory in Equity Crowdfunding. Small Business Economics, 46(4), 579-590.

Vismara, S. (2018). Information Cascades Among Investors in Equity Crowdfunding. Entrepreneurship Theory and Practice, 42(3), 467-497.

Wang, W., Mahmood, A., Sismeiro, C., et al. (2019). The Evolution of Equity Crowdfunding: Insights from Co-investments of Angels and the Crowd. Research Policy, 48(8), 103727.

Westlund, H., \& Bolton, R. (2003). Local Social Capital and Entrepreneurship. Small Business Economics, 21(2), 77-113. 
Wu, W., Huang, X., Li, Y., et al. (2018). Optimal Quality Strategy and Matching Service on Crowdfunding Platforms. Sustainability, 10(4), 1-17.

Xu, J. J., \& Chau, M. (2018). Cheap Talk? The Impact of Lender-Borrower Communication on Peer-to-Peer Lending Outcomes. Journal of Management Information Systems, 35(1), 53-85.

Yoon, Y., Li, Y., \& Feng, Y. (2019). Factors Affecting Platform Default Risk in Online Peer-to-Peer (P2P) Lending Business: An Empirical Study Using Chinese Online P2P Platform Data. Electronic Commerce Research, 19(1), 131-158.

Yum, H., Lee, B., \& Chae, M. (2012). From the Wisdom of Crowds to My Own Judgment in Microfinance Through Online Peer-to-Peer Lending Platforms. Electronic Commerce Research and Applications, 11(5), 469-483.

Zheng, H., Li, D., Wu, J., et al. (2014). The Role of Multidimensional Social Capital in Crowdfunding: A Comparative Study in China and US. Information \& Management, 51(4), 488-496.

Ziegler, T., Shneor, R., Wenzlaff, K., Odorovic, A., Johanson, D., Hao, R., \& Ryll, L. (2019). Shifting Paradigms: The 4th European Alternative Finance Benchmarking Report. Cambridge, UK: Cambridge Centre for Alternative Finance.

Open Access This chapter is licensed under the terms of the Creative Commons Attribution 4.0 International License (http://creativecommons.org/licenses/ by/4.0/), which permits use, sharing, adaptation, distribution and reproduction in any medium or format, as long as you give appropriate credit to the original author(s) and the source, provide a link to the Creative Commons licence and indicate if changes were made.

The images or other third party material in this chapter are included in the chapter's Creative Commons licence, unless indicated otherwise in a credit line to the material. If material is not included in the chapter's Creative Commons licence and your intended use is not permitted by statutory regulation or exceeds the permitted use, you will need to obtain permission directly from the copyright holder.

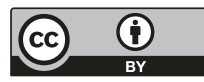

